\title{
ORIENTASI TUJUAN DAN EFIKASI AKADEMIK TERHADAP KECURANGAN AKADEMIK PADA MAHASISWA FAKULTAS PSIKOLOGI UIN RADEN FATAH PALEMBANG
}

\author{
Muhamad Uyun \\ Fakultas Psikologi, UIN Raden Fatah Palembang \\ Muhamaduyun74@gmail.com
}

\begin{abstract}
The research entitled goal orientation and academic efficacy to academic cheating on students of Faculty of Psychology UIN Raden Fatah Palembang. It begins the reality of education in Indonesia has not been quite successful in creating a whole person. It Looks from the are still splendid phenomenon that illustrates the moral decay of learners. One of them is a disturbing phenomenon of cheating behavior in this research is called academic cheating. This study aims to prove, how the influence of goal orientation and academic efficacy of academic cheating on students of the Faculty of Psychology UIN Raden Fatah. This type of correlational research because it explains the causal relationships that occur between variables, By using scale as a means of data collection. Data analysis use structural equation model (SEM) with program moment of structure analysis (AMOS.18).
\end{abstract}

Keywords: Goal Orientation; Academic Efficacy To Academic Cheating.

\begin{abstract}
ABSTRAK
Penelitian ini berjudul orientasi tujuan dan efikasi akademik terhadap kecurangan akademik pada mahasiswa Fakultas Psikologi UIN Raden Fatah Palembang. Hal ini bermula adanya realitas pendidikan di Indonesia belum cukup berhasil dalam menciptakan manusia seutuhnya.Tampak dari masih semaraknya berbagai fenomena yang mengambarkan rusaknya moral peserta didik. Salah satunya yang meresahkan adalah fenomena perilaku mencontek yang dalam penelitian ini disebut kecurangan akademik. Penelitian ini bertujuan membuktikan, bagaimana pengaruh orientasi tujuan dan efikasi akademik terhadap kecurangan akademik pada mahasiswa Fakultas Psikologi UIN Raden Fatah. Jenis penelitian korelasional karena menjelaskan hubungan kausal yang terjadi antar variabel, menggunakan skala sebagai alat pengumpulan data. Analisis data mengunakan structural equation model (SEM) dengan program analysis moment of structure (AMOS.18).
\end{abstract}

Kata Kunci: Orientasi tujuan dan efikasi akademik, dan kecurangan akademik.

\section{PENDAHULUAN}

Pendidikan memberikan peran penting untuk menghasilkan manusia yang cerdas, yaitu manusia yang bercakrawala pandangan luas, mampu memecahkan berbagai masalah dalam bidang kehidupan, yang selalu berorientasi ke depan. Sektor pendidikan formal tidak dapat diandalkan sepenuhnya untuk mewujudkan kualitas SDM yang handal dan berkwalitas, namun dapat dipastikan bahwa sektor pendidikan yang terorganisir dengan baik dan didukung oleh itikad pemerintah dapat memberikan peran signifikan dalam menghasilkan produk pendidikan yang berkwalitas.

Khususnya dalam konteks pendidikan di perguruan tinggi, mahasiswa diharapkan dapat menunjukkan perilaku belajar dengan 
baik, tekun dan jujur dalam setiap proses akademik yang mereka tempuh sehingga mereka mampu menjadi mahasiswa yang berkualitas dan siap menghadapi tantangan zaman. Namun dalam kenyataan masih ditemukan mahasiswa yang tidak menunjukkan proses belajar yang baik bahkan sering mengambil jalan pintas yang keliru dalam proses belajar. Kenyataanya pendidikan di Indonesia belum berhasil dalam menciptakan manusia seutuhnya. Hal ini tampak masih semaraknya fenomena yang mengambarkan rusaknya moral peserta didik. Salah satu yang sangat meresahkan adalah perilaku mencontek yang dalam penelitian ini disebut kecurangan akademik.

Peraturan yang dikeluarkan Menteri Pendidikan Nasional perihal pencegahan dan penanggulangan plagiat di Perguruan Tinggi, plagiat diartikan sebagai "Perbuatan secara sengaja atau tidak sengaja dalam memperoleh atau mencoba memperoleh kredit atau nilai untuk suatu karya ilmiah, dengan mengutip sebagian atau seluruh karya dan/ atau karya ilmiah pihak lain yang diakui sebagai karya ilmiahnya, tanpa menyatakan sumber secara tepat dan memadai". Dalam Permendiknas tersebut karya ilmiah tidak hanya terbatas pada tulisan melainkan mencakup pula piranti lunak, komposisi musik, fotografi, sketsa, patung dan lain sebagainya.

Lebih rinci pasal 2 Permendiknas menyatakan: Plagiat meliputi tetapi tidak terbatas pada: a. mengacu dan atau mengutip istilah, kata-kata dan atau kalimat, data dan atau informasi dari suatu sumber tanpa menyebutkan sumber dalam catatan kutipan dan atau tanpa menyatakan sumber secara memadai; b. Mengacu dan atau mengutip secara acak istilah, kata-kata dan atau kalimat data dan atau informasi dari suatu sumber tanpa menyebutkan sumber dalam catatan kutipan dan atau tanpa menyatakan sumber secara memadai; c. Menggunakan sumber gagasan, pendapat, pandangan, atau teori tanpa menyatakan sumber secara memadai; $d$. Merumuskan dengan kata-kata dan atau kalimat sendiri dari sumber kata-kata dan/atau kalimat, gagasan, pendapat, pandangan, atau teori tanpa menyatakan sumber secara memadai; e. Menyerahkan suatu karya ilmiah yang dihasilkan dan atau telah dipublikasikan oleh pihak lain sebagai karya ilmiahnya tanpa menyatakan sumber secara memadai" (Nasional, 2010).

Apa yang dijelaskan di atas menunjukkan bahwa kecurangan akademik telah melanda tingkatan pendidikan bahkan mahasiswa di perguruan tinggi. Mulyawati dkk (2010) menyatakan bahwa produktifitas pendidikan di Indonesia sangat rendah. Proses belajar mengajar dalam lembaga pendidikan gagal untuk mendidik generasi muda yang diidamkan. Sistem pendidikan menghasilkan manusia yang tidak jujur (curang) yang kemudian menjelma menjadi seorang polisi, guru, dokter, jaksa, pengusaha, hakim, dan profesi lainnya yang bisa lebih melakukan tindak ketidakjujuran yang lebih canggih lagi.

Stone (2010) menyatakan bahwa terdapat 3 komponen yang mempengaruhi intensi seseorang untuk melakukan perilaku tertentu yaitu: 1) sikap individu terhadap perilaku, 2) norma subjektif individu 3) persepsi tentang kemampuan mengontrol perilaku. Merujuk pada TPB, siswa tidak akan melakukan kecurangan akademik meskipun memiliki sikap yang positif terhadap kecurangan akademik dan dikelilingi oleh teman-teman yang melakukan kecurangan akademik ketika pengawasan sangat ketat sehingga mustahil untuk melakukan kecurangan.

Kecurangan akademik sebagai perilaku tidak jujur yang meliputi, menyerahkan tugas yang bukan karya sendiri, berkolaborasi dengan pelajar lain pada saat ujian, meminta bantuan pada anggota keluarga untuk menyelesaikan tugas, mengutip tanpa mencantumkan sumber, 
mencontek, berbohong kepada institusi ketika tidak mampu menyelesaikan tugas tepat waktu (Klein, 2011).

Jensen, Arnett dan Feldman (2002) menyatakan bahwa jenis kecurangan akademis yang dilakukan pelajar adalah sebagai berikut: 1) kecurangan dalam melaksanakan ujian, 2) kecurangan dalam membuat tugas rumah, dan 3) plagiat.

Selanjutnya McCabe dan Trevino (1997) menuturkan bahwa secara umum kecurangan akademik dapat dikategorikan ke dalam tiga aspek utama yaitu: 1) pada saat ujian, 2) pada saat menyusun tugas (paper, makalah ataupun tugas akhir), dan 3) pada saat aktifitas akademis lain.

Adapun tujuan dari penelitian ini yaitu untuk mengetahui hubungan antara orientasi tujuan, efikasi akademik terhadap kecurangan akademik pada mahasiswa di fakultas psikologi UIN Raden Fatah Palembang.

\section{METODE PENELITIAN}

\section{Jenis Penelitian}

Jenis penelitian yang digunakan adalah explanatory research atau penelitian penjelasan. Penelitian penjelasan adalah penelitian yang menjelaskan hubungan kausal antar variabel-variabel melalui pengajuan hipotesa. Penelitian explanatory research karena hendak menjelaskan hubungan kausal yang terjadi antara, variabel orientasi tujuan dan efikasi akademik terhadap kecurangan akademik .

\section{Tempat dan Waktu Penelitian}

Penelitian ini dilakukan pada mahasiswa di fakultas psikologi Universitas Islam Negeri Raden Fatah. Adapun waktu penelitian pada awal bulan Maret sampai dengan bulan Juli 2017.

\section{Identifikasi dan Definisi Operasional}

Dalam penelitian ini, terdapat tiga (3) variabel, satu (1) variabel tergantung yaitu kecurangan akademik dan 2 variabel bebas yaitu, orientasi tujuan dan efikasi akademik.

Kecurangan akademik adalah perilaku tidak jujur yang dilakukan oleh mahasiswa fakultas psikologi UIN RF Palembang, semasa mengikuti proses studi yang diukur sesuai dengan skala.

Orientasi tujuan adalah tujuan yang ingin dicapai oleh mahasiswa dalam belajar berupa tujuan yang berorientasi pembelajaran (learning goal orientation), tujuan berorientasi pembuktian (proving goal orientation) dan tujuan berorientasi penghindaran (avoiding goal orientation).

Efikasi akademik adalah kepercayaan mahasiswa Fakultas Psikologi UIN RF Palembang, terhadap kemampuannya sendiri untuk meregulasi (mengelola) kegiatan akademik meliputi membaca, mencatat, mempersiapkan ujian, menulis dan belajar.

\section{Populasi dan Teknik Sampling Populasi}

Populasi adalah keseluruhan subjek penelitian (Arikunto, 2010). Populasi dalam penelitian ini adalah seluruh mahasiswa di Fakultas Psikologi yaitu UIN Raden Fatah Palembang. sebagai berikut:

Tabel 1

Sebaran Populasi Penelitian

\begin{tabular}{cc}
\hline Semester & Jumlah Mahasiswa \\
\hline 2 & 120 \\
4 & 120 \\
6 & 80 \\
Total & 220 \\
\hline
\end{tabular}

\section{Sampel}

Menginggat jumlah populasi tidak terlalu besar, maka peneliti menjadikan seluruh populasi untuk dijadikan sampel penelitian, dengan demikian jumlah sampel pada penelitian ini berjumlah 220 mahasiswa fakultas psikologi UIN Raden Fatah Palembang. 


\section{Teknik Analisis Data}

Teknik analisis data yang digunakan untuk membahas permasalahan dalam penelitian ini adalah Structural Equation Model (SEM), yang dioperasikan melalui Program Analysis Moment of Structure (AMOS). Model SEM adalah teknik statistika yang memungkinkan pengujian suatu rangkaian hubungan yang relatif kompleks secara simultan. Hubungan yang kompleks dapat dibangun antara satu atau beberapa variabel dependen dengan satu atau beberapa variabel independen.

\section{HASIL DAN PEMBAHASAN}

\section{Uji Validitas dan Reliabilitas}

Dalam penelitian ini uji validitas dan reliabilitas dengan menggunakan model Confirmatory Factor Analysis (CFA). Analisis model pengukuran mengandung 3 langkah yaitu analisis kecocokan model (Overall Model Fit), nilai loading factor, dan nilai Construct Reliability (CR). Suatu indikator dinyatakan valid jika nnilai loading factor dari setiap indikator memiliki nilai $\geq$ 0,4 , begitu juga sebaliknya. Sedangkan kehandalan (reliabilitas) dari model pengukuran yang terbentuk dari indikator yang dinyatakan valid dilihat dari nilai Construct Reliability (CR). Tingkat kehandalan dinilai dari nilai $\mathrm{CR} \geq 0.70$.

\section{Uji Hipotesis}

Uji hipotesis untuk mengetahui hubungan vriabel dalam model struktural. Adapun hasil hubungan antar variabel ditunjukkan pada tabel regression weight (dalam AMOS). Pengujian hipotesis dilihat dari nilai Critical Ratio (CR) dan nilai Probability (p), dengan penggunaan statistik uji jika nilai CR berada di atas nilai 1,96 (alpha: 5\%) atai nilai probability lebih kecil dari pada alpha $(0,05)$ maka dapat isimpulkan bahwa terdapat pengaruh antar variabel. Adapun hasil pengujian menunjukan pengaruh antar variabel sesuai dengan hipotesis yang diajukan. Adapun hasil interprestasi tabel di atas sebagai berikut:

$H_{1}$ : Orientasi tujuan berpengaruh negatif terhadap kecurangan akademik

Hipotesis 1 dalam penelitian ini menyatakan bahwa orientasi tujuan berpengaruh negatif terhadap kecurangan akademik.

$\mathrm{H}_{2}$ : Efikasi akademik berpengaruh negatif terhadap kecurangan akademik

Hipotesis 2 dalam penelitian ini menyatakan bahwa efikasi akademik berpengaruh negatif terhadap kecurangan akademik.

Selanjutnya dilakukan analisis untuk mengetahui kontribusi pengaruh efikasi akademik, orientasi tujuan terhadap tingkat kecurangan akademik. Adapun hasil pengaruh langsung adalah orientasi tujuan memberikan kontribusi pengaruh terhadap tingkat kecurangan akademik sebesar 4,4\% (negatif).

Kontribusi yang diberikan merupakan kontribusi tingkat penurunan dari kecurangan akdemik dikarenakan adanya orientasi tujuan dalam diri mahasiswa. Sama halnya dengan efikasi akademik dalam diri mahasiswa akan mampu menurunkan tingkat kecurangan sebesar 24,5\% (negatif). Dapat disimpulkan bahwa faktor utama yang mampu menghindari dari tingkat kecurangan adalah adanya bentuk dari efikasi akademik, dimana kepercayaan akan kemampuan yang dimiliki dalam diri sendiri akan membangun sikap optimis untuk menjali tugas sebagai mahasiswa.

\section{Pengaruh Orientasi Tujuan Terhadap Kecurangan Akademik}

Orientasi tujuan menggambarkan tujuan pencapaian individual, hal ini penting karena orientasi tujuan dapat mempengaruhi konsekuensi motivasi, kognitif, dan perilaku mahasiswa. Berdasarkan hasil analisis di 
peroleh bahwa orientasi tujuan tidak berpengaruh terhadap kecurangan akademik. Orientasi yang terlihat dalam diri mahasiswa lebih dominan kepada orientasi pembuktian. Akan tetapi pembuktian yang ingin di perlihatkan mahasiswa bahwa dirinya lebih baik dari orang lain masih dalam batas wajar dan tidak berlebih. Hal ini dikarenakan terlalu memiliki rasa optimis yang berlebih akan kemampuan yang dimiliki akan memberikan perluang untuk bertindak curang.

Menurut Dweck dan Leggett (1988) dalam konteks pencapaian intelektual, tujuan dapat dikategorikan ke dalam dua jenis orientasi yaitu: a) tujuan berorientasi hasil (performance goals), hal yang paling penting bagi individu dengan tujuan ini adalah mendapatkan penilaian yang baik terhadap kemampuan yang mereka miliki, b) tujuan berorientasi pembelajaran (learning goals), yang paling penting bagi individu dengan tujuan ini adalah meningkatkan kemampuannya.

Mahasiswa yang memiliki orientasi tujuan dalam hal berbuat curang tidak akan manfaat apapun. Secara logika, jika mahasiswa benar-benar ingin belajar, mengerti, memahami, dan menguasai materi tertentu harus melakukan tindakan curang, karena tidak akan membantu untuk meraih tujuan dalam berkuliah. Mahasiswa dalam kelompok ini dapat melihat bahwa tujuan berkuliah adalah untuk memperoleh kompetensi di bidang yang diajarkan dan memperoleh grade yang memuaskan.

Sejauh ini mahasiswa memiliki tingkat orientasi tujuan yang positif dimana membuktikan lebih baik dari orang lain dengan jalan yang benar seperti belajar, mengerjakan tugas tepat waktu, aktif di dalam kampus, dan lain sebagainya. Mengandalkan dan mengasah kemampuan yang dimiliki justru akan lebih berguna kedepannya, ketimbang bertindak yang seharusnya tidak pantas dilakukan oleh seorang mahasiswa.
Akan tetapi pada kenyataannya tindakan yang menyimpang seperti mengerjakan tugas individu secara bersamaan, mengerjakan paper bersamaan dan copy paste dianggap sebagai hal yang sangat wajar. Beberapa mahasiswa mengatakan itu bukan tindakan curang melainkan sebagai bentuk solidaritas untuk saling bekerja sama memperoleh hasil yang sama pula. Berbeda ketika menghadapi ujian tengah semester, ujian semester yang pasti mengerjakan secara individu, dan ketika itu dilanggar baru dapat dikatakan curang. Sebagaimana yang sudah diketahui mahasiswa yang memiliki orientasi tujuan dalam kuliahnya justru kemungkinan kecil untuk bertindak curang. Orientasi dalam diri mahasiswa sebagai tameng untuk tidak melakukan perbuatan yang merugikan diri sendiri.

\section{Pengaruh Efikasi Akademik Terhadap Kecurangan Akademik}

Dikaitkan dengan konteks pendidikan, efikasi penting sekali artinya bagi keberhasilan siswa untuk menguasai pembelajaran. Bahkan, menurut Bandura (1997) efikasi akademik adalah prediktor yang lebih baik untuk memprediksi prestasi akademik dari pada keterampilan belajar aktual, semakin tinggi efikasi terhadap kemampuan mengelola motivasi dan aktifitas belajar, maka semakin tinggilah efikasi diri untuk menguasai pelajaran. Sehingga senada dengan Kitsantas dan Zimmerman (2009) pada akhirnya efikasi akademik akan mempengaruhi prestasi akademis.

Efikasi diri dalam setting akademik disebut efikasi akademik. Efikasi akademik pada dasarnya merupakan keyakinan yang dimiliki seseorang tentang kemampuan atau kompetensi dalam mengerjakan tugas, mencapai tujuan, dan mengatasi tantangan akademik.

Lebih lanjuut menurut Bandura (1997) efikasi memainkan peran yang sangat penting 
dalam konteks akademis, kepercayaan pelajar terhadap kemampuan mereka untuk melaksanakan kegiatan akademis akan mempengaruhi aspirasi, tingkat ketertarikan untuk mencari pengetahuan, prestasi akademis, dan bagaimana cara pelajar dalam mempersiapkan diri untuk menjalani karir.

Hasil penelitian tersebut menunjukkan bahwa efikasi diri atau keyakinan pada kemampuan diri untuk mengatur dan melakukan serangkaian tindakan yang diperlukan dalam mencapai tujuan yang diukur melalui tiga dimensi yaitu level, generality, dan strength berpengaruh negatif terhadap kecurangan akademik. Dalam hal ini bisa dikatakan bahwa efikasi diri yang tinggi mengurangi tingkat kecurangan akademik seorang peserta didik.

Senada dengan itu, Gosooly dan Ghanizadeh (2011) menyatakan bahwa pelajar dengan efikasi akademis yang baik cenderung berusaha lebih keras, gigih dalam menghadapi hambatan, optimis, memiliki level kecemasan yang rendah dan meraih pencapaian yang lebih tinggi dari pada pelajar dengan efikasi akademis rendah.

Bandura (1997) membedakan self efficacy, dimensi-dimensi self efficacy antara lain yaitu Magnitude (tingkat kesulitan tugas), Generality (luas bidang tugas atau perilaku), Strength (kemantapan atau keyakinan).

Efikasi diri menjadikan seorang peserta didik berusaha untuk mencapai tujuan belajarnya dengan kemampuan sendiri, sehingga tidak perlu lagi melakukan tindakan kecurangan akademik.

Hasil penelitian ini senada dengan hasil penelitian yang dilakukan oleh Nora, Yan, Zhang dan Chen (2010) menunjukkan bahwa siswa yang melakukan perilaku kecurangan akademik memiliki efikasi diri yang rendah. Mahasiswa dengan efikasi tinggi akan cenderung untuk memperbaiki diri sendiri dalam pembelajaran maupun tindakantindakan yang dapat membangun diri sendiri sehingga menghasilkan suatu hasil yang memuaskan.

\section{SIMPULAN}

Berdasarkan hasil penelitian dan pembahasan di atas diperoleh kesimpulan bahwa Orientasi tujuan tidak berpengaruh terhadap tingkat kecurangan akademik mahasiswa Fakultas Psikologi UIN Raden Fatah Palembang. Artinya mahasiswa yang memiliki orientasi tujuan saat ini dalam berkuliah tidak memacu terjadinya tingkat kecurangan Hal ini dikarenakan orientasi tujuan yang ada dalam diri mahasiswa adalah pembuktian atas kemampuan yang dimiliki untuk memperoleh hasil yang memuaskan.

Efikasi akademik berpengaruh negatif terhadap tingkat kecurangan akademik. Artinya semakin tinggi tingat efikasi mahasiswa akan berdampak pada tidak melakukan tindakan curang. Hal ini dikarenakan dengan adanya efikasi akademik dalam diri mahasiswa akan mampu menjaga, memotivasi dan mengelola emosi, mengontrol diri sendiri ketika menghadapi tekanan, permasalahan dalam akademik. Biasanya mahasiswa yang seperti ini adalah mahasiswa yang memiliki tingkat orientasi yang tinggi dalam akdemiknnya.

\section{SARAN}

Berdasarkan simpulan di atas, adapun peneliti mengajukan saran untuk mendorong pihak-pihak terkait menelaah hasil dari temuan penelitian ini. Adapun saran yang diajukan sebagai berikut:

\section{Bagi mahasiswa Fakultas Psikologi}

Bentuk dari tingakan kecurangan sangat beragam, akan tetapi ketika sudah melakukan tindakan yang seharusnya tidak dilakukan hal tersebut sudah memiliki kategori yang salah. Walaupun dalam konteks kerja sama, saling toleransi, akan tetapi tidak sesuai dengan intruksi yang seharusnua dikerjakan. Oleh karena itu 
perlu adanya pemahaman lebih lanjut tentan arti belajar, dimana merubah sikap dan perilaku untuk berbuat yang baik itu salah satu cara untuk menghindari kegiatan yang curang.

2. Bagi lingkup UIN Raden Fatah Palembang Perlu adanya evaluasi lanjut dari pihak lingkup UIN Raden Fatah Palembang, untuk melakukan pengembangans upaya dapat memeproleh cara dan strategi untuk mengatasi hal tersebut.

\section{DAFTAR PUSTAKA}

Arikunto, S. (2010). Prosedur Penelitian Suatu Pendekatan Praktik. Jakarta: Rineka Cipta.

Bandura, A. (1997). Self Efficcay: The Exercize of Control. New York: W. H. Freeman and Company.

Dweck, C. S., \& Legget, E. L. (1988). A Social-Cognitive Approach to Motivation and Personality. American Psychological Association, 95.

Ghonsooly, B., \& Ghanizadeh, A. (2011). Self Efficacy And Self Regulation And Their Relationship: A Study Of Iranian EFL Teachers. United Kingdom: Routledge.

Jensen, L. A. (2002). It's Wrong, But Everybody Does It: Academic Dishonety among High School and College Student. Contemporary Educational Psychology.

Kitsantas, A., \& Zimmerman, B. J. (2009). College Students' Homework and Academic Achievement: The Mediating Role of Self-Regulatory Belief. United State of America: Business Media.

Klein, D. (2011). Why Learners Choose Plagiarism: a Review of Literatures. Minot: Minot State University.

McCabe, D. L., \& Trevino, L. K. (1997). Individual and Contextual Influences on Academic Dishonesty: A
Multicampus Investigation. Research in Higher Education, 38 (3), 379-396. Mulyawati, H., Masturoh, I., Anwaruddin, I., \& Mulya. (2010). Pembelajaran Studi Sosial. Bandung: Alfabeta.

Nasional, M. P. (2010, Agustus 16). Peraturan Menteri Pendidikan Nasional Republik Indonesia Nomor 17 Tahun 2010 Tentang Pencegahan dan Penanggulangan Plagiat di Perguruan Tinggi. Jakarta.

Nora, Yan, W. L., Zhang, \& Chen, K. (2010). Motives of Cheating among Secondary Students: The Role of SelfEfficacy and Peer Influence Nora. Asia Pacific Education Review , 11 (4), 573-584.

Stone, T. H. (2010). Predicting Academic Misconduct Intentions and Behavior Using the Theory of Planned Behavior and Personality. New York: Taylor \& Francis Group: Psychology Press. 